\title{
Pittosporum bernardii
}

\author{
Assessment by: Gemmill, C., Veillon, J.-M., Amice, R., Cazé, H., Dumontet, V., \\ Fleurot, D., Garnier, D., Gâteblé, G. \& Maggia, L.
}

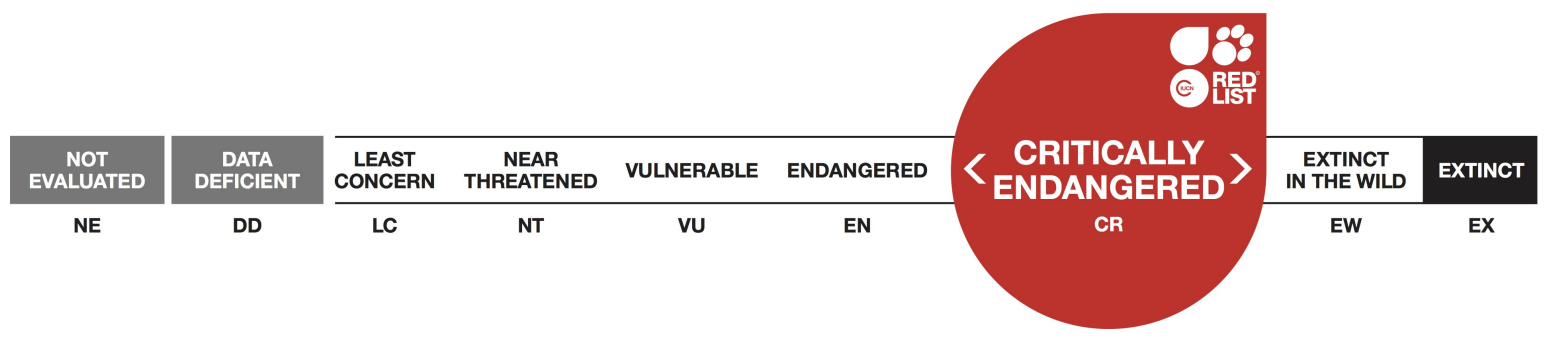

View on www.iucnredlist.org

Citation: Gemmill, C., Veillon, J.-M., Amice, R., Cazé, H., Dumontet, V., Fleurot, D., Garnier, D., Gâteblé, G. \& Maggia, L. 2017. Pittosporum bernardii. The IUCN Red List of Threatened Species 2017: e.T82946620A82951757. http://dx.doi.org/10.2305/IUCN.UK.20173.RLTS.T82946620A82951757.en

Copyright: @ 2017 International Union for Conservation of Nature and Natural Resources Reproduction of this publication for educational or other non-commercial purposes is authorized without prior written permission from the copyright holder provided the source is fully acknowledged.

Reproduction of this publication for resale, reposting or other commercial purposes is prohibited without prior written permission from the copyright holder. For further details see Terms of Use.

The IUCN Red List of Threatened Species ${ }^{T M}$ is produced and managed by the IUCN Global Species Programme, the IUCN Species Survival Commission (SSC) and The IUCN Red List Partnership. The IUCN Red List Partners are: Arizona State University; BirdLife International; Botanic Gardens Conservation International; Conservation International; NatureServe; Royal Botanic Gardens, Kew; Sapienza University of Rome; Texas A\&M University; and Zoological Society of London. 


\section{Taxonomy}

\begin{tabular}{|c|c|c|c|c|}
\hline Kingdom & Phylum & Class & Order & Family \\
\hline Plantae & Tracheophyta & Magnoliopsida & Rosales & Pittosporaceae \\
\hline
\end{tabular}

Taxon Name: Pittosporum bernardii Tirel \& Veillon

\section{Taxonomic Source(s):}

Tirel, Ch. and Veillon, J.-M. 2002. Flore de la Nouvelle-Calédonie, tome 24. Pittosporaceae. Museum d'Histoire Naturelle, Paris.

\section{Assessment Information}

Red List Category \& Criteria: Critically Endangered B1ab(iii)+2ab(iii) ver 3.1

Year Published:

Date Assessed:
2017

July 23, 2015

\section{Justification:}

Pittosporum bernardii is an endemic shrub known from a single locality on the main island of New Caledonia: Oui Pouin. Since the first collection in 1965, it has never been seen again despite field surveys. It occurs in the undergrowth of humid forest at an altitudinal range 500-700 m asl. Pittosporum bernardii could have gone extinct due to combined pressures from recurrent bushfires and the presence of invasive Rusa Deer (Rusa timorensis); however, surveys are required to determine if it is still extant or not. With an area of occupancy and extent of occurrence of $4 \mathrm{~km}^{2}$ and an estimation of continuous decline in habitat quality, P. bernardii qualifies for listing as Critically Endangered (CR) B1ab(iii)+2ab(iii).

\section{Geographic Range}

\section{Range Description:}

Pittosporum bernardii is an endemic shrub known from only a single locality on the main island of New Caledonia: Oui Pouin.

\section{Country Occurrence:}

Native: New Caledonia 


\section{Distribution Map}

\section{Pittosporum bernardii}

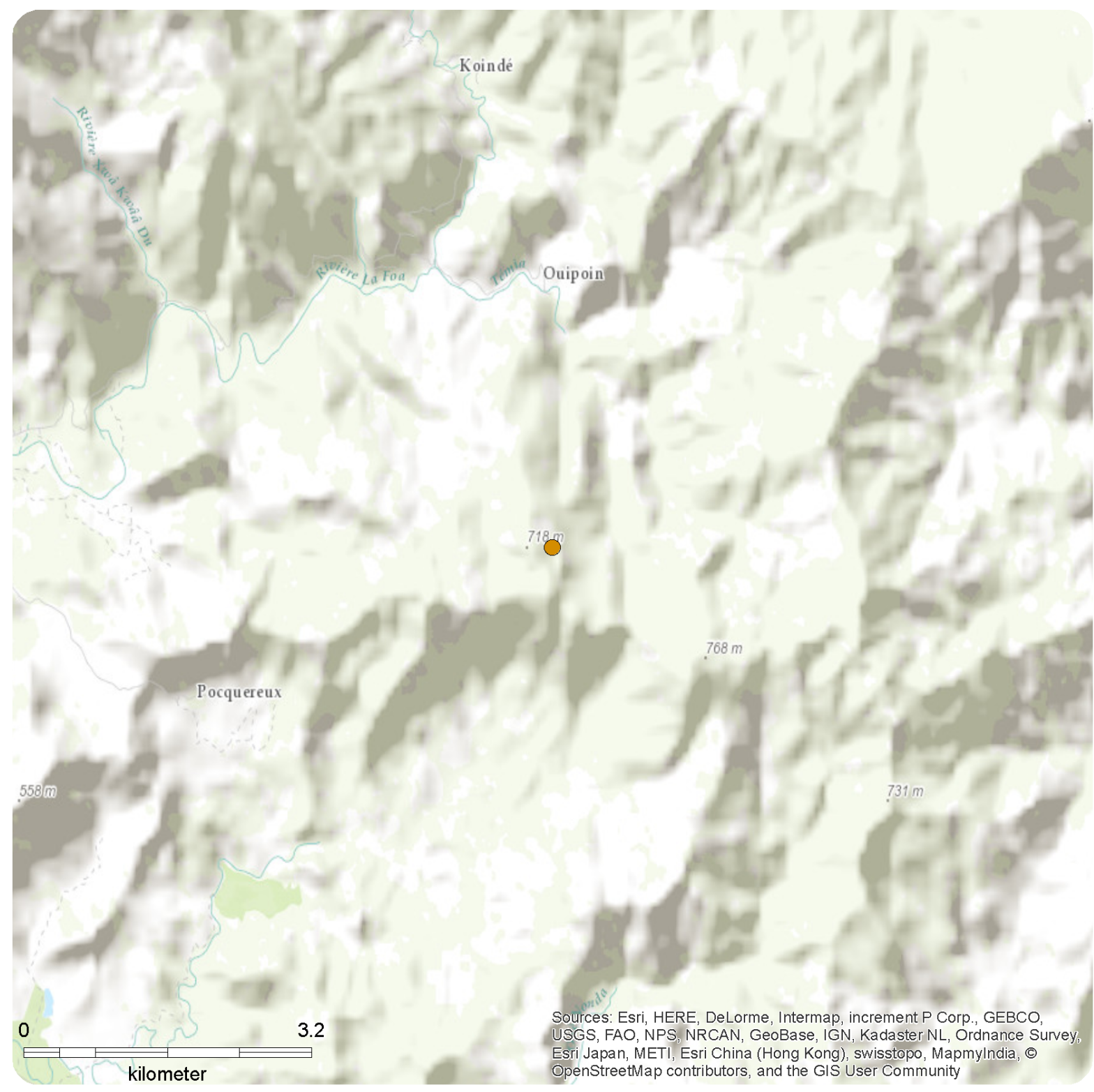

Range

Extant (resident)
Compiled by:

IUCN SSC New Caledonia Plants RLA

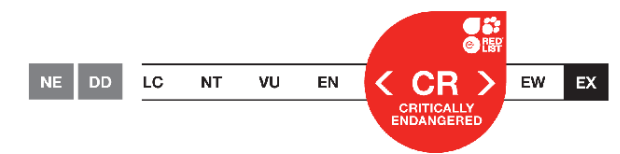




\section{Population}

Population size is unknown due to a lack of data.

Current Population Trend: Decreasing

\section{Habitat and Ecology (see Appendix for additional information)}

Pittosporum bernardii occurs in the undergrowth of humid forest on schist and greywacke at an altitudinal range 500-700 $\mathrm{m}$ asl.

Systems: Terrestrial

\section{Threats (see Appendix for additional information)}

According to its distribution, Pittosporum bernardii is threatened by Rusa Deer, frequent fires, and mining activities, which form the three major threats to the New Caledonian flora.

\section{Conservation Actions (see Appendix for additional information)}

Pittosporum bernardii is not protected by any legislation and does not occur in any protected areas. In order to confirm the survival of this species, surveys at the Oui-Pouin locality are urgently needed, as well as at Koghis, corresponding to an old collection from Balansa. A count of mature individuals will enable the population dynamics to be monitored. To improve knowledge on New Caledonian species of Pittosporum, and especially the relatedness between $P$. heckelii and $P$. bernardii, further research, such as fine-scale phylogenetic and ecological studies, are urgently required.

\section{Credits}

Assessor(s): $\quad$ Gemmill, C., Veillon, J.-M., Amice, R., Cazé, H., Dumontet, V., Fleurot, D., Garnier, D., Gâteblé, G. \& Maggia, L.

Reviewer(s): $\quad$ Tanguy, V.

Facilitators(s) and Chanfreau, S.

Compiler(s): 


\section{Bibliography}

Endemia.nc. 2016. Faune et Flore de Nouvelle-Calédonie. Available at: http://www.endemia.nc.

Gomez, C., Mangeas, M., Curt, T., Ibanez, T., Munzinger, J., Dumas, P., Jérémy, A., Despinoy, M. and Hély, C. 2014. Wildfire risk for main vegetation units in a biodiversity hotspot: modeling approach in New Caledonia, South Pacific. Ecology and Evolution 5(2): 377-390. DOI: 10.1002/ece3.1317.

Hély-Alleaume. 2012. INC : Incendies et biodiversité des éco-systèmes en Nouvelle-Calédonie.

IUCN. 2017. The IUCN Red List of Threatened Species. Version 2017-3. Available at: www.iucnredlist.org. (Accessed: 7 December 2017).

Tirel, Ch. and Veillon, J.-M. 2002. Flore de la Nouvelle-Calédonie, tome 24. Pittosporaceae. Museum d'Histoire Naturelle, Paris.

\section{Citation}

Gemmill, C., Veillon, J.-M., Amice, R., Cazé, H., Dumontet, V., Fleurot, D., Garnier, D., Gâteblé, G. \& Maggia, L. 2017. Pittosporum bernardii. The IUCN Red List of Threatened Species 2017: e.T82946620A82951757. http://dx.doi.org/10.2305/IUCN.UK.2017-3.RLTS.T82946620A82951757.en

\section{Disclaimer}

To make use of this information, please check the Terms of Use.

\section{External Resources}

For Images and External Links to Additional Information, please see the Red List website. 


\section{Appendix}

\section{Habitats}

(http://www.iucnredlist.org/technical-documents/classification-schemes)

\begin{tabular}{|c|c|c|c|}
\hline Habitat & Season & Suitability & $\begin{array}{l}\text { Major } \\
\text { Importance? }\end{array}$ \\
\hline 1. Forest -> 1.6. Forest - Subtropical/Tropical Moist Lowland & - & Suitable & - \\
\hline
\end{tabular}

\section{Threats}

(http://www.iucnredlist.org/technical-documents/classification-schemes)

\begin{tabular}{|c|c|c|c|c|}
\hline Threat & Timing & Scope & Severity & Impact Score \\
\hline \multirow{3}{*}{$\begin{array}{l}\text { 3. Energy production \& mining }->3.2 \text {. Mining \& } \\
\text { quarrying }\end{array}$} & Ongoing & - & - & - \\
\hline & Stresses: & \multirow{2}{*}{\multicolumn{3}{|c|}{$\begin{array}{l}\text { 1. Ecosystem stresses }->1.1 \text {. Ecosystem conversion } \\
\text { 1. Ecosystem stresses }->1.2 \text {. Ecosystem degradation }\end{array}$}} \\
\hline & & & & \\
\hline \multirow{4}{*}{$\begin{array}{l}\text { 7. Natural system modifications }->7.1 \text {. Fire } \& \text { fire } \\
\text { suppression }->7.1 .1 \text {. Increase in fire } \\
\text { frequency/intensity }\end{array}$} & Ongoing & - & - & - \\
\hline & Stresses: & \multirow{3}{*}{\multicolumn{3}{|c|}{$\begin{array}{l}\text { 1. Ecosystem stresses }->1.1 \text {. Ecosystem conversion } \\
\text { 1. Ecosystem stresses }->1.2 \text {. Ecosystem degradation } \\
\text { 2. Species Stresses }->\text { 2.1. Species mortality }\end{array}$}} \\
\hline & & & & \\
\hline & & & & \\
\hline \multirow{3}{*}{$\begin{array}{l}\text { 8. Invasive and other problematic species, genes } \& \\
\text { diseases }->8.1 \text {. Invasive non-native/alien } \\
\text { species/diseases }->8.1 .2 \text {. Named species (Rusa } \\
\text { timorensis) }\end{array}$} & Ongoing & - & - & - \\
\hline & Stresses: & \multirow{2}{*}{\multicolumn{3}{|c|}{$\begin{array}{l}\text { 2. Species Stresses }->2.2 \text {. Species disturbance } \\
\text { 2. Species Stresses }->2.3 \text {. Indirect species effects }-> \\
\text { 2.3.7. Reduced reproductive success }\end{array}$}} \\
\hline & & & & \\
\hline
\end{tabular}

\section{Conservation Actions in Place}

(http://www.iucnredlist.org/technical-documents/classification-schemes)

\begin{tabular}{|l|}
\hline Conservation Actions in Place \\
\hline In-Place Land/Water Protection and Management \\
\hline Occur in at least one PA: No \\
\hline Invasive species control or prevention: No \\
\hline In-Place Species Management \\
\hline Successfully reintroduced or introduced beningly: No \\
\hline Subject to ex-situ conservation: No \\
\hline
\end{tabular}

\section{Research Needed}


(http://www.iucnredlist.org/technical-documents/classification-schemes)

\section{Research Needed}

1. Research $\rightarrow$ 1.1. Taxonomy

1. Research $->1.2$. Population size, distribution $\&$ trends

3. Monitoring -> 3.1. Population trends

\section{Additional Data Fields}

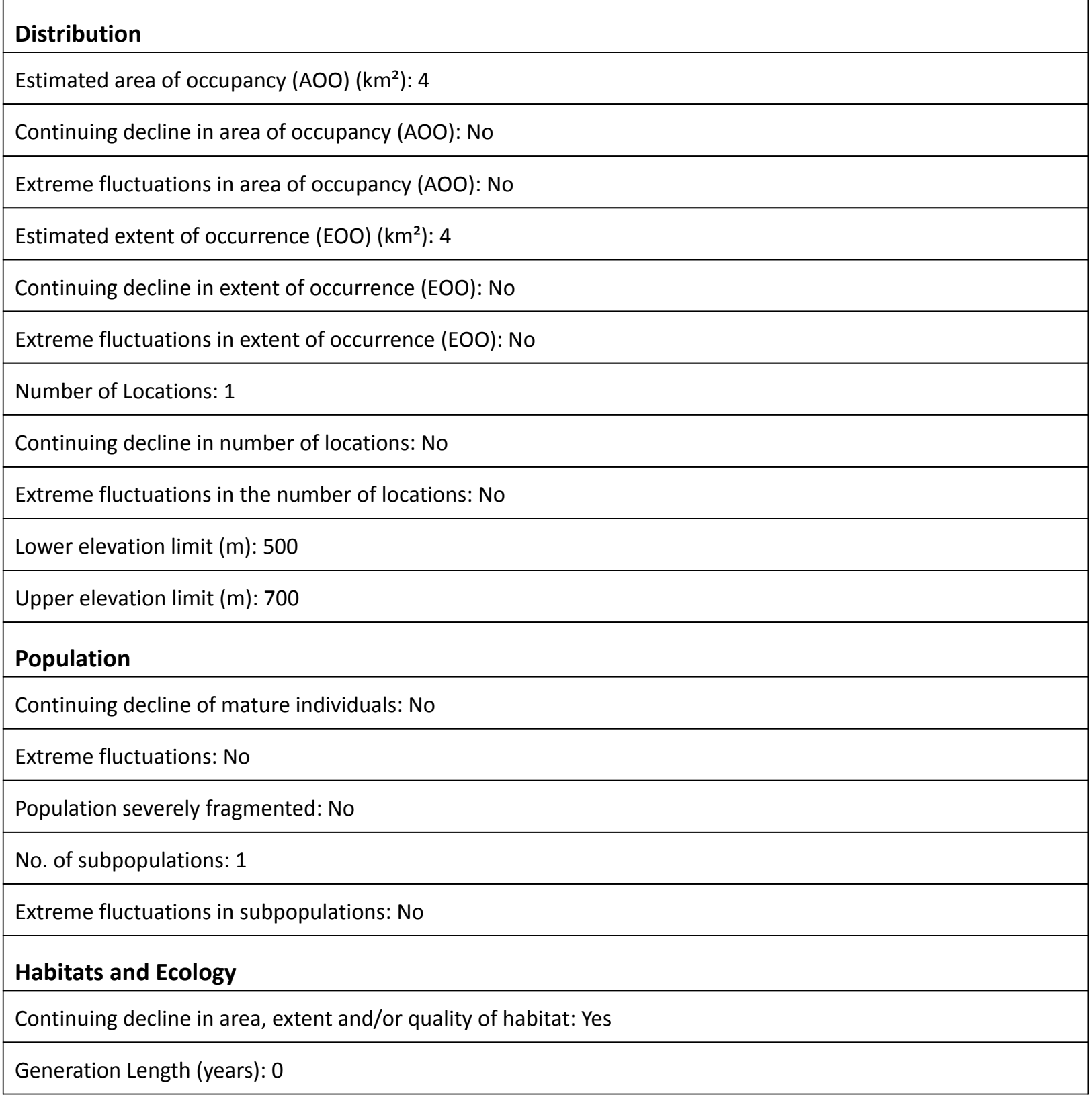




\section{The IUCN Red List Partnership}

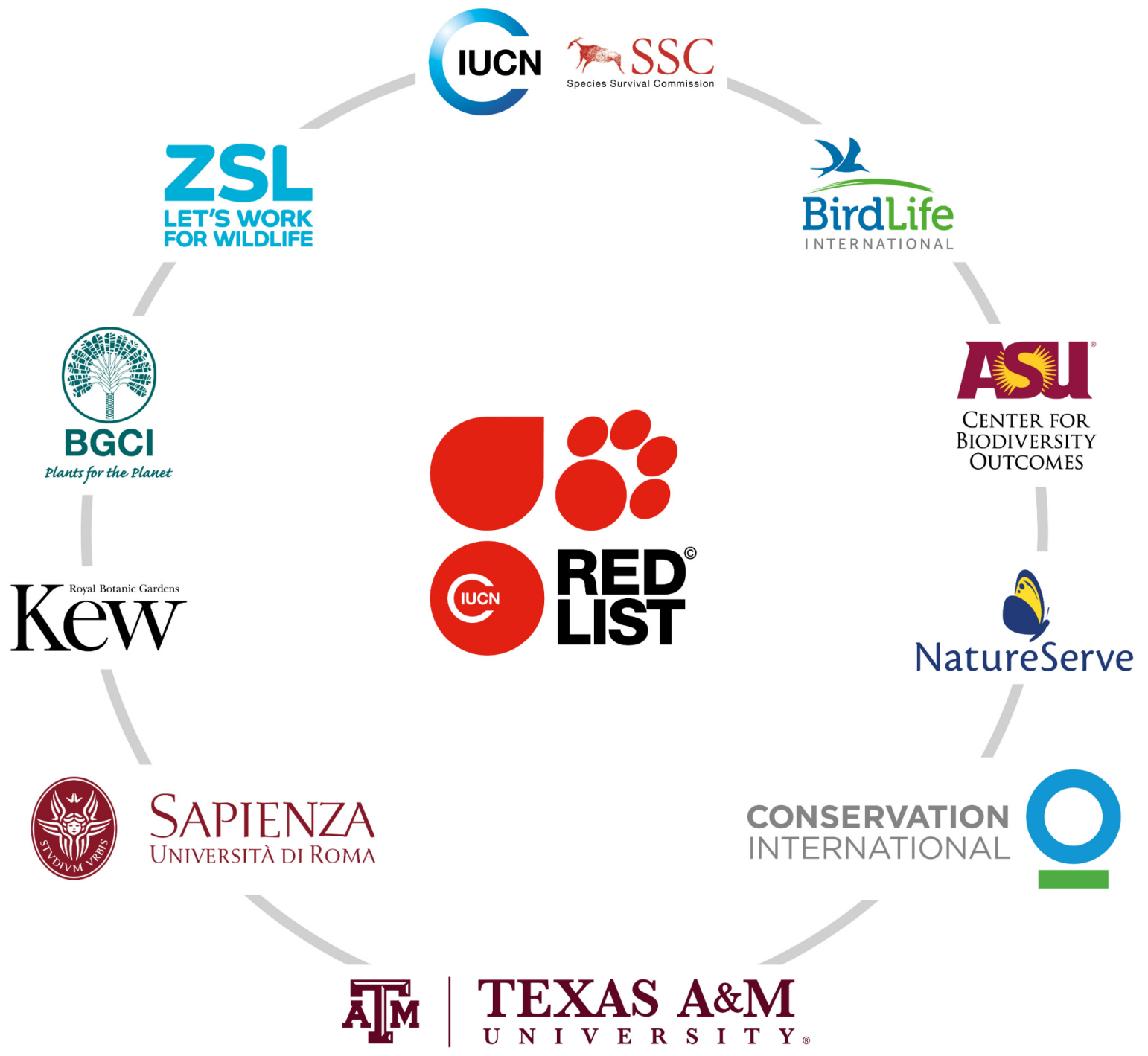

The IUCN Red List of Threatened Species ${ }^{\mathrm{TM}}$ is produced and managed by the IUCN Global Species Programme, the IUCN Species Survival Commission (SSC) and The IUCN Red List Partnership.

The IUCN Red List Partners are: Arizona State University; BirdLife International; Botanic Gardens Conservation International; Conservation International; NatureServe; Royal Botanic Gardens, Kew; Sapienza University of Rome; Texas A\&M University; and Zoological Society of London. 